\title{
AGRONOMIC EFFICIENCY AND GROWTH OF EGGPLANT CROP UNDER DIFFERENT POTASSIUM AND NITROGEN DOSES ${ }^{1}$
}

\author{
ÁLVARO HENRIQUE CÂNDIDO DE SOUZA ${ }^{2 *}$, ROBERTO REZENDE ${ }^{2}$, MARCELO ZOLIN LORENZONI ${ }^{2}$, CÁSSIO \\ DE CASTRO SERON ${ }^{2}$, FERNANDO ANDRÉ SILVA SANTOS ${ }^{2}$
}

\begin{abstract}
Fertilization is important for the optimization of plant growth and yield, which are necessary for agronomic activities. Soil fertilization should increase net earnings that depend on nutrient use efficiency. The aim of this study was to evaluate the agronomic efficiency of eggplant under different doses of potassium $(\mathrm{K})$ and nitrogen $(\mathrm{N})$. Four levels of $\mathrm{K}\left(0,54,108\right.$, and $\left.216 \mathrm{~kg} \mathrm{ha}^{-1}\right)$ and four levels of $\mathrm{N}(0,67,134$, and $268 \mathrm{~kg} \mathrm{ha}^{-1}$ ) were applied weekly by fertigation. The highest plant and the largest stem diameter were found with $165-175 \mathrm{~kg} \mathrm{ha}^{-1}$ of $\mathrm{N}$. Leaf area was more influenced by $\mathrm{N}$ than by K. Isolated application of different $\mathrm{K}$ doses did not statistically influence height plant, stem diameter, or leaf dry matter. The agronomic efficiency of nitrogen is reduced with increasing levels of $\mathrm{N}$ and $\mathrm{K}$.
\end{abstract}

Keywords: Mineral nutrition. Fertigation. Protected environment. Solanum melongena L..

\section{EFICIÊNCIA AGRONÔMICA E CRESCIMENTO DA CULTURA DA BERINJELA SOB DIFERENTES DOSES DE POTÁSSIO E NITROGÊNIO}

RESUMO - A adubação é importante para otimizar o crescimento e produtividade, sendo necessario para atividade agrícola. A adubação de solo deve aumentar o lucro liquido, que depende da eficiência de uso de nutrientes pela planta. $\mathrm{O}$ objetivo deste estudo foi avaliar a eficiência agronômica em berinjela sob diferentes doses de potássio $(\mathrm{K})$ e nitrogênio $(\mathrm{N})$. Quatro níveis de $\mathrm{K}\left(0,54,108\right.$ e $\left.216 \mathrm{~kg}_{\text {de }} \mathrm{K}^{-1} \mathrm{ha}^{-1}\right)$ e quatro níveis de $\mathrm{N}$ $\left(0,67,134\right.$ e $268 \mathrm{~kg}$ de $\left.\mathrm{N} \mathrm{ha}^{-1}\right)$ foram aplicados semanalmente via fertirrigação. As plantas mais altas e com maior diâmetro de caule foram obtidas com 165-175 kg ha ${ }^{-1}$ de N. A área foliar foi mais influenciada pelo nitrogênio em comparação com o potássio. Aplicações isoladas de diferentes doses de K não influenciaram a altura de planta, diâmetro de caule e matéria seca da folha. A eficiência agronômica do nitrogênio é reduzida com o aumento da dose de $\mathrm{N}$ e $\mathrm{K}$.

Palavras-chave: Nutrição mineral. Fertirrigação. Ambiente protegido. Solanum melongena L..

\footnotetext{
"Corresponding author

${ }^{1}$ Received for publication in $03 / 09 / 2017$; accepted in $01 / 22 / 2018$.

Paper extracted from the dissertation of the first author

${ }^{2}$ Department of Agronomy, Universidade Estadual de Maringá, Maringá, PR, Brazil; alvarohcs@hotmail.com - ORCID: 0000-0002-83671242, rrezende@uem.br - ORCID: 0000-0002-6213-1845, marcelorenzoni@hotmail.com - ORCID: 0000-0001-8547-9505, cassioseron@msn.com - ORCID: 0000-0003-4289-931X, fernan.agr@hotmail.com - ORCID: 0000-0003-2220-1914.
} 


\section{INTRODUCTION}

Eggplant (Solanum melongena L.) is an important vegetable in Brazil and worldwide and belongs to the Solanaceae family (SILVA et al., 2015). It has been cultivated in protected environments as a strategy for horticulturists to increase competitiveness, resulting in larger products that can be harvested continuously (MARQUES et al., 2011).

Eggplant responds well to nitrogen $(\mathrm{N})$, phosphorus, and potassium $(\mathrm{K})$ fertilization (OLONIRUHA, 2011). $\mathrm{N}$ fertilization increases the growth and yield of eggplant due to the effects of the nutrient on carbohydrate influx and the synthesis of regulators in growing plants (AMINIFARD et al., 2010).

$\mathrm{N}$ deficiency decreases growth and results in chlorotic leaves caused by lean assimilate formation, which predates flowering and leads to shortening of the cycle (AZARPOUR et al., 2012). Azarpour et al. (2012) observed increased eggplant production with $\mathrm{N}$ application. Aminifard et al. (2010) reported that $100 \mathrm{~kg} \mathrm{ha}^{-1}$ of $\mathrm{N}$ resulted in the highest fruit yield of eggplant.

$\mathrm{K}$ is a macronutrient required by fruits and vegetables, which regulates cell turgor, activates enzymes involved in respiration, and controls stomatal opening and closure (FAQUIN; ANDRADE, 2004). K levels affect the total yield and fruit quality of eggplant (FAWZY; EL-NEMR; SALEH, 2007; HOCHMUTH; HOCHMUTH; DONLEY, 1993).

Nutritional stress is one of the main factors limiting crop productivity; this may occur due to an excess or a deficit of nutrients. Accurate fertilization techniques are needed to prevent nutritional stress. Drip fertigation systems are successful agricultural tools, mainly for the precise application of $\mathrm{N}, \mathrm{K}$, and micronutrients (FELEAFEL; MIRDAD, 2013).

Correct fertigation management in the cultivation of protected environments is important due of the lack of rain; that is, balanced application must consider the varying demands over time to reduce the possibility of salinity.

Plants only absorb part of the nutrients supplied by fertilization (OLIVEIRA et al., 2008). One way to evaluate nutrient use efficiency is to calculate the agronomic efficiency, which is the ratio of production to the unit of applied nutrient (FAGERIA, 1998).

With the aim of providing adequate nutrition for eggplant crops, studies on the effects of $\mathrm{N}$ and $\mathrm{K}$ fertilization must be conducted to better address the needs of the crop and to increase the utilization efficiency of these nutrients. Therefore, the aim of the present study was to investigate the growth and agronomic efficiency of eggplant under different doses $\mathrm{K}$ and $\mathrm{N}$ doses.

\section{MATERIAL AND METHODS}

Eggplant S. Melongena L. 'Ciça' was grown in a protected environment located in the Irrigation Technical Center of the State University of Maringá, Paraná, Brazil $\left(23^{\circ} 25^{\prime} 57^{\prime \prime} \mathrm{S}\right.$ latitude; $51^{\circ} 57^{\prime} 08^{\prime \prime} \mathrm{W}$ longitude; altitude of $542 \mathrm{~m}$ above sea level), from February to August 2015. The classification of this location is a temperate climate with a hot summer (Cfa), according to the Koppen-Geiger climate classification (PEEL; FINLAYSON; MCMAHON, 2007).

Soil samples were collected from the $0.0-0.20 \mathrm{~m}$ soil layer and classified as Latossolo Vermelho Distrófico (Oxisol). Particle size was analyzed as described by Ferrari et al. (2014), and the results showed that the texture was sandy (190, 30 , and $780 \mathrm{~g} \mathrm{~kg}^{-1}$ clay, silt, and sand). Soil chemical analysis was conducted in accordance with the methods described by Embrapa (2011). Soil contained: $8.63 \mathrm{mg} \mathrm{dm}$ of $\mathrm{P}, 2.10 \mathrm{mg} \mathrm{dm}^{-3}$ of $\mathrm{Na}^{+}$, $0.07 \mathrm{cmol}_{\mathrm{c}} \mathrm{dm}^{-3}$ of $\mathrm{K}^{+}, 1.56 \mathrm{cmol}_{\mathrm{c}} \mathrm{dm}^{-3}$ of $\mathrm{Ca}^{2+}$, $0.38 \mathrm{cmol}_{\mathrm{c}} \mathrm{dm}^{-3}$ of $\mathrm{Mg}^{2+}, 0.7 \mathrm{cmol}_{\mathrm{c}} \mathrm{dm}^{-3}$ of $\mathrm{Al}^{3+}$, $2.48 \mathrm{cmol}_{\mathrm{c}} \mathrm{dm}^{-3}$ of $\mathrm{H}^{+}$, and $4.66 \mathrm{~g} \mathrm{dm}^{-3}$ of organic matter. Liming and basal fertilization were performed 60 days prior to transplantation with the application of $333 \mathrm{~kg}$ of dolomitic limestone, $312 \mathrm{~kg}$ of $\mathrm{P}_{2} \mathrm{O}_{5}, 105 \mathrm{~kg}$ of $\mathrm{K}$, and $5200 \mathrm{~kg}$ of organic compost per hectare.

On February 21, eggplant seeds were seeded in polyethylene trays filled with a commercial substrate based on pine bark. On April 9, one seedling was transplanted into a plastic pot of approximately $25 \mathrm{dm}^{3}$ (diameter $31 \mathrm{~cm}$ and depth $35 \mathrm{~cm}$ ), containing $25 \mathrm{~kg}$ of air-dried soil. The drainage system consisted of a non-sealed bottom, with $4 \mathrm{~kg}$ of $\mathrm{n}^{\circ} 1$ crushed stone, sufficient to fill the bottom of the pot. A non-woven fabric disk was placed over the crushed stone to avoid losing the finer fraction of the soil.

One drip irrigation (3.9 $\mathrm{L} \mathrm{h}^{-1}$ ) was used in each experimental unit, operating at a pressure of 10 m.w.c. Irrigation was controlled by weighing the pots daily using a digital scale with a capacity of $40.0 \mathrm{~kg}( \pm 2.0 \mathrm{~g})$. When soil water tension approached the critical tension of $-15 \mathrm{kPa}$ (BILIBIO et al., 2010), corresponding to $0.08 \mathrm{~g} \mathrm{~g}^{-1}$, the soil was irrigated until the moisture in the pot reached field capacity $\left(0.2 \mathrm{~g} \mathrm{~g}^{-1}\right)$ (CASAROLI; JONG VAN LIER, 2008).

Four doses of $\mathrm{K}$ were applied using $\mathrm{KCl}(0$, 54,108 , and $216 \mathrm{~kg} \mathrm{ha}^{-1}$ of $\mathrm{K}$ ) to supplement the basal fertilization with $\mathrm{K}\left(105 \mathrm{~kg} \mathrm{ha}^{-1}\right.$ of $\left.\mathrm{K}\right)$. Four doses of $\mathrm{N}$ were applied using urea $(0,67,134$, and $268 \mathrm{~kg} \mathrm{ha}^{-1}$ of N). The experiment was arranged in a completely randomized design including four $\mathrm{K}$ doses, four $\mathrm{N}$ doses, and four replicates, for a total of 16 treatments and 64 pots. All the pots were re-randomized once per week to minimize any positional effects. The plants were spaced $0.8 \mathrm{~m}$ 
apart, and lateral rows were spaced $1.2 \mathrm{~m}$ apart.

Total doses of $\mathrm{N}$ and $\mathrm{K}$ were previously fractionated for weekly fertigation, according to the nutrient absorption capacity of eggplant crop (TRANI; TIVELLI; CARRIJO, 2011). First and second, third and fourth; fifth to tenth, and eleventh to sixteenth weeks, $3.45,5.17,8.62$, and $5.17 \%$ of the total dose per week. The fertilizers were diluted in $1 \mathrm{~L}\left(1 \mathrm{dm}^{3}\right)$ of water and applied during irrigation.

Fruits with a shiny dark purple color were harvested 100 to 137 days after transplanting (DAT). To evaluate the eggplant growth in response to different doses of $\mathrm{K}$ and $\mathrm{N}$, the plant height $(\mathrm{PH}$ $[\mathrm{cm}]$ ), and stem diameter (SD [mm]), were measured $21,35,49,63,77,91,105$, and 137 DAT. At the end of the cycle, the leaf area (LA $\left[\mathrm{cm}^{2}\right.$ per plant]), and leaf dry matter, (LDM [g per plant]), were measured.

Agronomic efficiency of fertilizers was calculated by dividing the difference in production with fertilization minus the production without fertilization, per amount of applied nutrient. Agronomic efficiency of $\mathrm{N}$ (AEN), and agronomic efficiency of K (AEK), were given as described by Fageria (1998) and Oliveira et al. (2008). AEN and AEK are reported as kilogram fruit yield per kilogram fertilizer applied $\left(\mathrm{kg} \mathrm{kg}^{-1}\right)$.

The minimum and maximum temperatures were obtained through an automatic weather station to calculate the degrees day (DD). The data were obtained from transplantation (2015-04-10) until the last evaluation of growth (2015-07-23). The DD was determined in accordance with the methodology proposed by Ometto (1981). The highest and lowest temperatures considered to calculate DD, were 16 and $35^{\circ} \mathrm{C}$.

Data were analyzed using the program Sisvar 5.6. The $F$ test at a 0.05 probability level was applied; were significance was found, regression analysis was applied. The statistical model selection criterion considered: Student's t-test for the regression coefficients $(p<0.05)$ and adjustment of the coefficient of determination ( $\left.\mathrm{R}^{2} \mathrm{adj}\right)$. The complete model considered was: $\mathrm{Z}=\beta_{0}+\beta_{1}(\mathrm{X})+\beta_{2}(\mathrm{Y})+\beta_{3}(\mathrm{X})^{2}+\beta_{4}(\mathrm{Y})^{2}+\beta_{5}(\mathrm{X})(\mathrm{Y})$ where: $Z$ is the estimated value for the characteristic studied; $\beta_{0}, \beta_{1}, \beta_{2}, \beta_{3}, \beta_{4}$, and $\beta_{5}$ are the regression coefficients, and $\mathrm{X}$ and $\mathrm{Y}$ are predictive variables.

\section{RESULTS AND DISCUSSION}

The leaf area (LA) of eggplants was significantly influenced $(p<0.05)$ by the isolated application of $\mathrm{K}$ and $\mathrm{N}$, and by their interaction (Table 1). According to the adjusted model, fertigation with $\mathrm{K}$ and $\mathrm{N}$ doses increased the LA of eggplant to the highest value $\left(18,249.6 \mathrm{~cm}^{2}\right.$ per plant) with $116.5 \mathrm{~kg} \mathrm{ha}^{-1}$ of $\mathrm{K}$ and $268 \mathrm{~kg} \mathrm{ha}^{-1}$ of $\mathrm{N}$ (Figure 1). High $\mathrm{K}$ doses reduced the LA in the data best fitted to the quadratic equation. Following the trend of the equation, we can state that $\mathrm{N}$ doses exceeding $348 \mathrm{~kg} \mathrm{ha}^{-1}$ reduced the LA. According to the adjusted multivariate model, the increase in LA was greater for one kilogram of $\mathrm{N}$ than for one kilogram of $\mathrm{K}$.

Feleafel and Mirdad (2013) fertigated eggplant on sandy soil (91.1\% sand) weekly and obtained the maximum value of LA with $250 \mathrm{~kg} \mathrm{ha}^{-1}$ of $\mathrm{K}$ and $250 \mathrm{~kg} \mathrm{ha}^{-1}$ of N. Fawzy, El-Nemr and Saleh (2007) reported the highest vegetative growth with LA when using $300 \mathrm{~kg} \mathrm{ha}^{-1}$ of $\mathrm{K}$. The $\mathrm{K}$ doses used by those researchers are similar to the results of the present study, considering the total $\mathrm{K}$ dose $\left(221.5 \mathrm{~kg} \mathrm{ha}^{-1}\right.$ of $\left.\mathrm{K}\right)$, basal fertilization (105 kg ha ${ }^{-1}$ of K), plus $116.5 \mathrm{~kg} \mathrm{ha}^{-1}$ of $\mathrm{K}$.

Table 1. Summary of the analysis of variance for leaf area (LA $\left[\mathrm{cm}^{2}\right.$ per plant]), leaf dry matter (LDM [g per plant]), plant height $(\mathrm{PH}[\mathrm{cm}])$, stem diameter (SD [mm]), agronomic efficiency of nitrogen (AEN) and potassium (AEK) $\left(\mathrm{kg} \mathrm{kg}^{-1}\right)$. CV: coefficient of variation; $\mathrm{F}$ values: ns: non-significant at the 0.05 level; *significant at the 0.05 level; **significant at the 0.01 level.

\begin{tabular}{|c|c|c|c|c|c|}
\hline \multirow{3}{*}{ Variables } & & ation sources & & \multirow{3}{*}{$\mathrm{CV}(\%)$} & \multirow{3}{*}{ Average } \\
\hline & Potassium $(\mathrm{K})$ & Nitrogen $(\mathrm{N})$ & $\mathrm{N} \times \mathrm{K}$ & & \\
\hline & \multicolumn{3}{|c|}{$\ldots \ldots \ldots \ldots \ldots \ldots \ldots \ldots \ldots . . \mathrm{F}$ values } & & \\
\hline LA & $5.202^{* *}$ & $182.807^{* *}$ & $3.570^{* *}$ & 19.18 & 9843.86 \\
\hline LDM & $1.049^{\mathrm{ns}}$ & $157.046^{* *}$ & $2.058^{*}$ & 19.75 & 54.54 \\
\hline PH & $0.475^{\mathrm{ns}}$ & $12.113^{*}$ & $0.609^{\mathrm{ns}}$ & 9.10 & 78.26 \\
\hline SD & $1.415^{\mathrm{ns}}$ & $12.303^{* *}$ & $3.229^{* *}$ & 7.04 & 14.95 \\
\hline AEN & $7.840^{* *}$ & $154.070^{* *}$ & $9.478^{* *}$ & 19.70 & 137.72 \\
\hline AEK & $7.278^{* *}$ & $56.390^{* *}$ & $17.031^{* *}$ & 20.60 & -12.85 \\
\hline
\end{tabular}




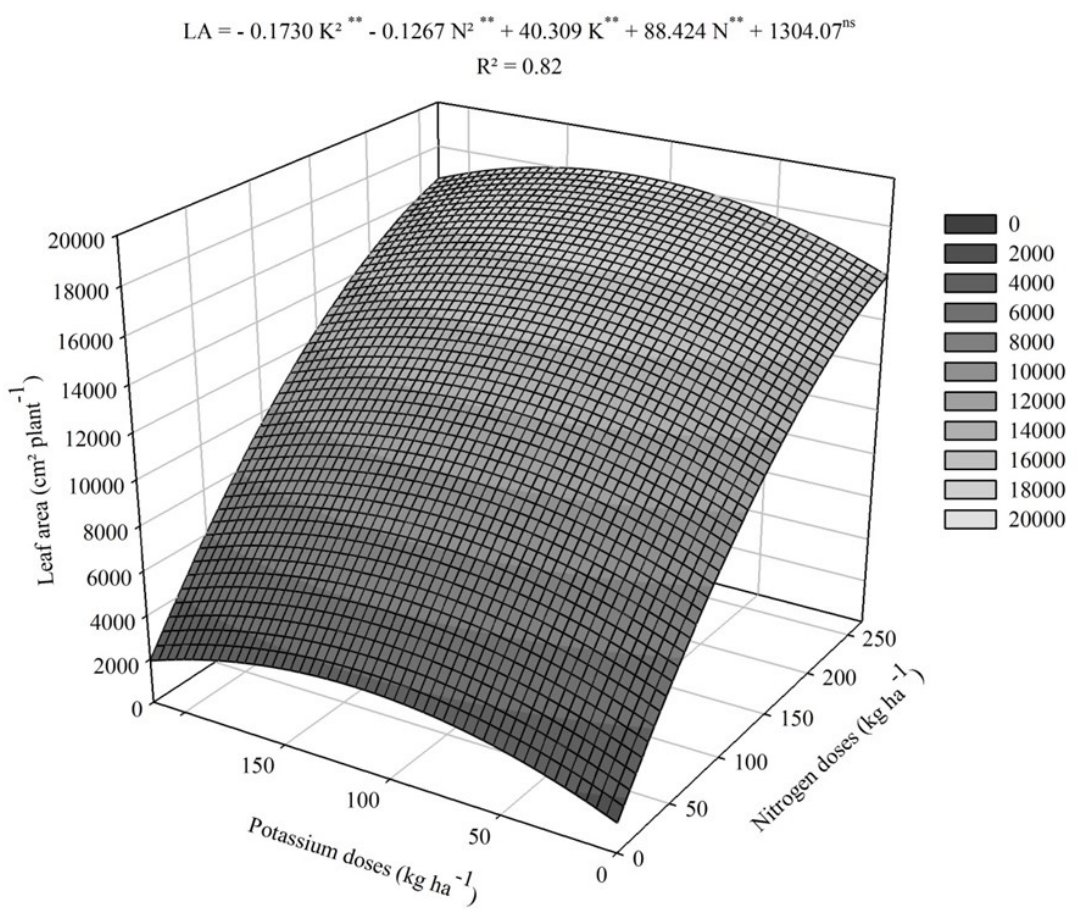

Figure 1. Leaf area of eggplant as a function of $\mathrm{K}$ and $\mathrm{N}$ doses cultivated in a protected environment.

According to the analysis of variance, leaf dry matter (LDM) was significantly affected by the interaction between $\mathrm{K}$ and $\mathrm{N}$ doses (Table 1). The individual effect of $\mathrm{K}$ application was not significant. The maximum LDM (106.9 g per plant) was obtained with $268 \mathrm{~kg} \mathrm{ha}^{-1}$ of $\mathrm{N}$ and $54 \mathrm{~kg} \mathrm{ha}^{-1}$ of $\mathrm{K}$ (Figure 2). $\mathrm{N}$ fertilization promoted increments of $501.5,549.8,360.6$, and $512.1 \%$ of LDM in relation to the initial value, considering the levels $\mathrm{K} 1$ $\left(0 \mathrm{~kg} \mathrm{ha}^{-1}\right), \mathrm{K} 2\left(54 \mathrm{~kg} \mathrm{ha}^{-1}\right), \mathrm{K} 3\left(108 \mathrm{~kg} \mathrm{ha}^{-1}\right)$, and K4 $\left(216 \mathrm{~kg} \mathrm{ha}^{-1}\right)$, respectively.

In a study of eggplant culture, Marques et al. (2011) observed a reduction in the dry matter of leaves and stem with doses of $\mathrm{K}$ higher than $592.9 \mathrm{~kg} \mathrm{ha}^{-1}$ at $120 \mathrm{DAT}$ using $\mathrm{KCl}$. According to those authors, the reduction in dry matter indicates that the plants may have been stressed in response to soil salinity at high doses.

Aminifard et al. (2010) reported a reduction in the dry matter of eggplant leaves with $\mathrm{N}$ at a dose $150 \mathrm{~kg} \mathrm{ha}^{-1}$ of N. Meanwhile, Amiri, Gohari and Esmailian (2012) and Oloniruha (2011) showed that application of $\mathrm{N}$ in the range $120-180 \mathrm{~kg} \mathrm{ha}^{-1}$ resulted in the highest number of leaves per plant.

According to França et al. (2011) who studied corn crop, $\mathrm{N}$ availability can affect vegetative growth, influencing LA. LA is related to the interception of solar radiation and assimilation of carbon for the culture; high $\mathrm{N}$ availability results in higher accumulation of LDM, uptake of $\mathrm{N}$, and income of the culture. For eggplant culture, it is probable that those relationships are similar when the LA and the LDM are considered, i.e. an appropriate supply of the nutrient can result in higher availability and therefore, in higher values for those variables.

The results for plant height indicated significant effects of $\mathrm{N}$ fertigation (Table 1). For this variable, it was possible to adjust a quadratic model, such that the highest plant $(82.8 \mathrm{~cm})$ was obtained with fertigation of $175 \mathrm{~kg} \mathrm{ha}^{-1}$ of $\mathrm{N}$ and the shortest plant height $(70.59 \mathrm{~cm})$ was obtained without nitrogen fertigation (Figure 3). The results corroborate those of Lima et al. (2014), who found the highest eggplant plants with $200 \mathrm{~kg} \mathrm{ha}^{-1}$ of $\mathrm{N}$, obtaining $68.14 \mathrm{~cm}$. Additionally, Bozorgi (2012) reported the maximum plant height $(111.5 \mathrm{~cm})$ between 60 and $90 \mathrm{~kg} \mathrm{ha}^{-1}$ of $\mathrm{N}$.

Aminifard et al. (2010) noted that plant height can be considered a vigor index, which depends on vigor and plant growth. They evaluated eggplants at 10, 30, and 50 DAT and found no significant differences between $\mathrm{N}$ doses of 50, 100, and $150 \mathrm{~kg} \mathrm{ha}^{-1}$. Significant differences were found compared with $0 \mathrm{~kg} \mathrm{ha}^{-1}$ of $\mathrm{N}$, which promoted the development of the shortest plants. Other studies have shown that the shortest plants developed in the shortest N dose (AMIRI; GOHARI; ESMAILIAN, 2012; MIRDAD, 2011; OLONIRUHA, 2011; LIMA et al., 2014); this is because $\mathrm{N}$ is the second-most absorbed nutrient for eggplants after K (HAAG; HOMA, 1968). 


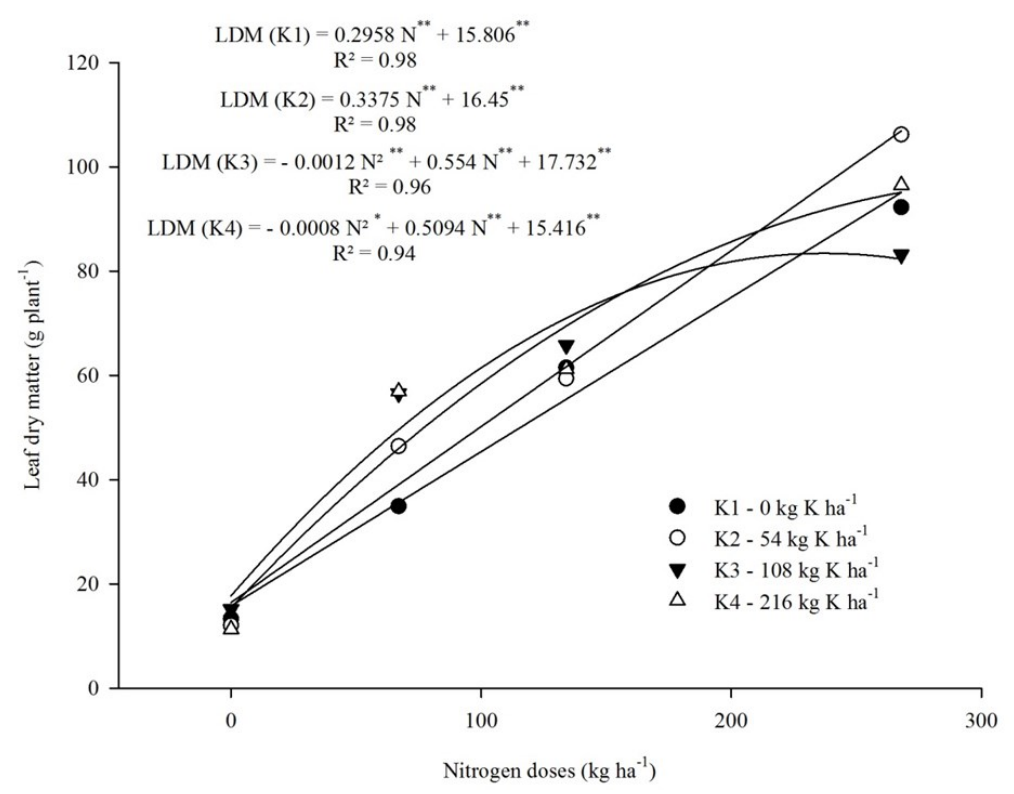

Figure 2. Leaf dry matter as a function of $\mathrm{N}$ dose in eggplants subjected to different $\mathrm{K}$ doses cultivated in a protected environment.

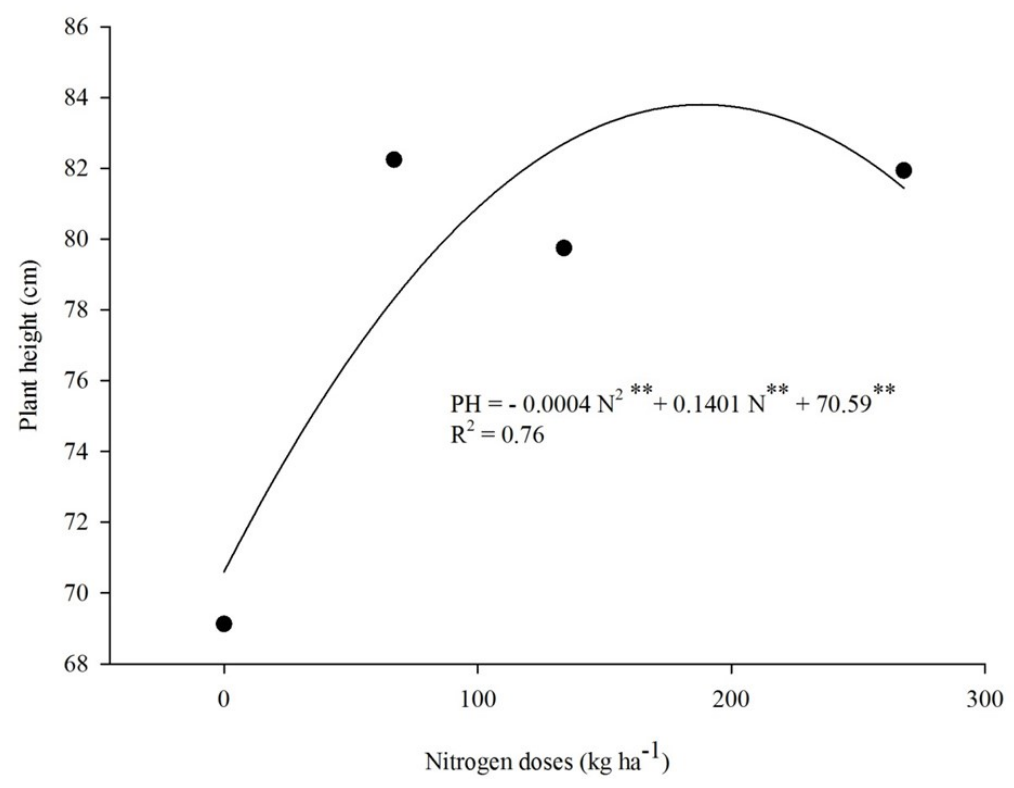

Figure 3. Eggplant height as a function of $\mathrm{N}$ dose, cultivated in a protected environment.

There was a significant interaction between $\mathrm{N}$ and $\mathrm{K}$ on stem diameter (SD); however, the adjustment of complete regression models was not possible, with the quadratic model only adjusted for the general effects of $\mathrm{N}$ (Figure 4).

The maximum SD $(15.8 \mathrm{~mm})$ was obtained with $165 \mathrm{~kg} \mathrm{ha}^{-1}$ of $\mathrm{N}$, with higher doses causing a decrease in SD. Lima et al. (2014) applied up to $200 \mathrm{~kg} \mathrm{ha}^{-1}$ of N and found no significant differences in eggplant SD. Oloniruha (2011) obtained the largest diameter with $130 \mathrm{~kg} \mathrm{ha}^{-1}$ of $\mathrm{N}$; this is close to the dose required to reach the maximum SD. Mirdad (2011) applied different $\mathrm{N}$ doses in two eggplant cycles. The first cycle resulted in larger SD
$(2.46 \mathrm{~cm})$ with $300 \mathrm{~kg} \mathrm{ha}^{-1}$ of $\mathrm{N}$, and the second obtained 2.61 and $2.62 \mathrm{~cm}$ with 200 and $300 \mathrm{~kg} \mathrm{ha}^{-1}$ of $\mathrm{N}$, respectively.

It is possible that $\mathrm{N}$ has important effects on growth variables at several stages. According to Lopes and Lima (2015), high levels of $\mathrm{N}$ are required by all cultivated plants. $\mathrm{N}$ influences protein synthesis and the production of new plant tissue, since carbon metabolism supplies energy for the incorporation of $\mathrm{N}$. Therefore, it is possible that the correct supply of $\mathrm{N}$ results in a high height and $\mathrm{SD}$ due to the maintenance of appropriate metabolic activity in the eggplant. 


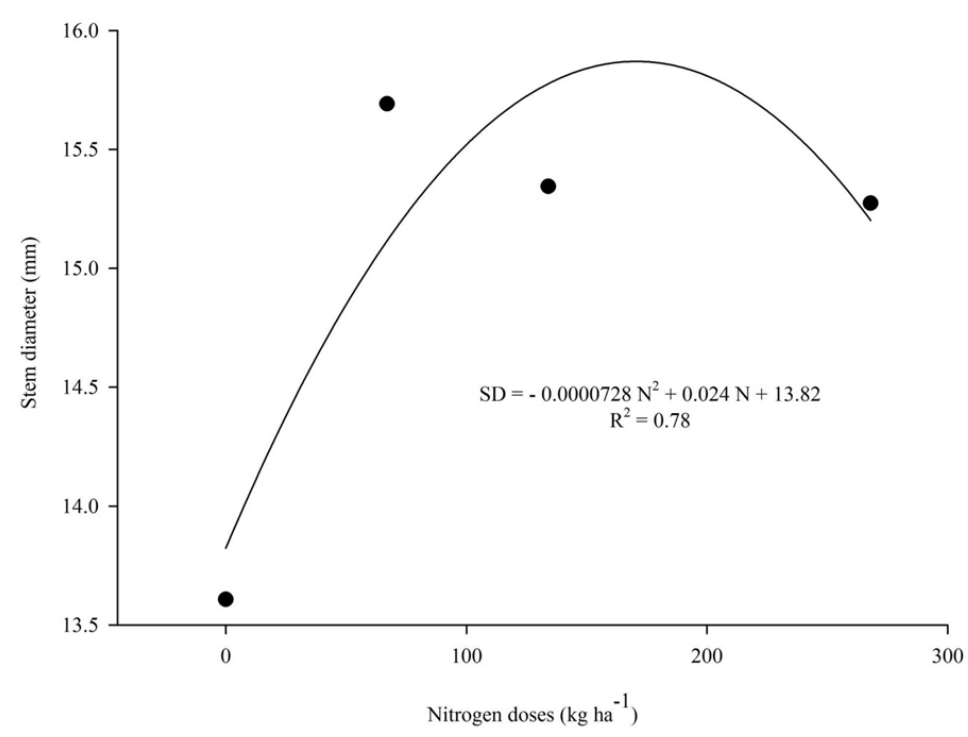

Figure 4. Stem diameter of eggplant as a function of $\mathrm{N}$ dose, cultivated in a protected environment.

The daily average temperature over the growing season ranged from 13.3 to $31.2^{\circ} \mathrm{C}$ and the average relative humidity was $62.5 \%$. Climatological data registered during the experiment were used to calculate the sum of degrees day (DD). The values for $\mathrm{DD}$ as a function of days after transplanting (DAT) were: 0 (0), 193 (21), 310 (35), 399 (49), 485 (63), 567 (77), 622 (91), and 691 (105).

Variance analyses for $\mathrm{PH}$ and $\mathrm{SD}$ as a function of the sum of DD subjected to different NA doses were significant at a $1 \%$ level of probability.

The data were fitted to a Sigmoid function, as utilized by Melo et al. (2010), which plotted PH and $\mathrm{SD}$ as a function of DAT. As shown in Figure 5A, $\mathrm{PH}$ increases slowly up to approximately $200 \mathrm{DD}$. After $200 \mathrm{DD}$, the $\mathrm{PH}$ increases quickly, with the maximum growth rate reported at $380 \mathrm{DD}(0.165 \mathrm{~cm}$ $\left.\mathrm{DD}^{-1}\right)$. Minami, Simão and Mantovani (1980) showed that eggplants grow quickly after 42 DAT; this value was between 310 and 399 DD. The maximum growth rate reported for SD $(0.0218 \mathrm{~mm}$ $\mathrm{DD}^{-1}$ ) occurred at $360 \mathrm{DD}$ (Figure 5B). According to Trani, Tivelli and Carrijo (2011), eggplant has the highest nutritional demand between 35 and 70 DAT.

Analysis of variance revealed no significant differences in eggplant growth for different doses of $\mathrm{N}$ at the first vegetative stages; however, growth differences were observed from 77 DAT.

There was an interaction between $\mathrm{K}$ and $\mathrm{N}$ dose for AEN, which allowed to fit a values surface in that $\mathrm{AEN}$ is a function of the $\mathrm{K}$ and $\mathrm{N}$ doses (Figure 6). $\mathrm{K}$ and $\mathrm{N}$ doses reduced the $\mathrm{AEN}$; however, $\mathrm{N}$ had a greater influence than $\mathrm{K}$. The effect of $\mathrm{K}$ on decreasing the AEN was considerable at high doses.

The best AEN value (280.5 kg fruit per $\mathrm{kg} \mathrm{N}$ ) was obtained in the absence of $\mathrm{K}$ and $\mathrm{N}\left(0 \mathrm{~kg} \mathrm{ha}^{-1}\right.$ for both). This was consistent with the findings of Oliveira et al. (2014), who examined the effect of water salinity and $\mathrm{N}$ fertilization on eggplant crop, and obtained the highest AEN (373 kg fruit per $\mathrm{kg} \mathrm{N}$ ) when lower doses were applied. Those authors showed that AEN decreased with increasing $\mathrm{N}$ doses, independent of the salinity of the irrigation water.

These results are not consistent with those obtained by Aujla, Thind and Buttar (2007), who studied irrigation methods and levels of $\mathrm{N}$, and confirmed an increase in AEN up to $120-150 \mathrm{~kg} \mathrm{ha}^{-1}$ of $\mathrm{N}$. However, of note, when calculating the agronomic efficiency of nutrients, those authors (AUJLA; THIND; BUTTAR, 2007; OLIVEIRA et al., 2014) did not consider the difference between productivity of the dose studied minus the productivity of the control treatment $\left(0 \mathrm{~kg} \mathrm{ha}^{-1}\right.$ of $\left.\mathrm{N}\right)$. Thus, their values were higher than if they had considered in numerator of division the productivity with fertilizer minus the productivity of the control treatment.

To guarantee that AEN and AEK would represent variation in production due to the amount nutrient of applied, and not due to the total amount of nutrient in the soil, the evaluation of agronomic efficiency considered the discount of control treatment productivities as described by Fageria (1998) and Oliveira et al. (2008). 

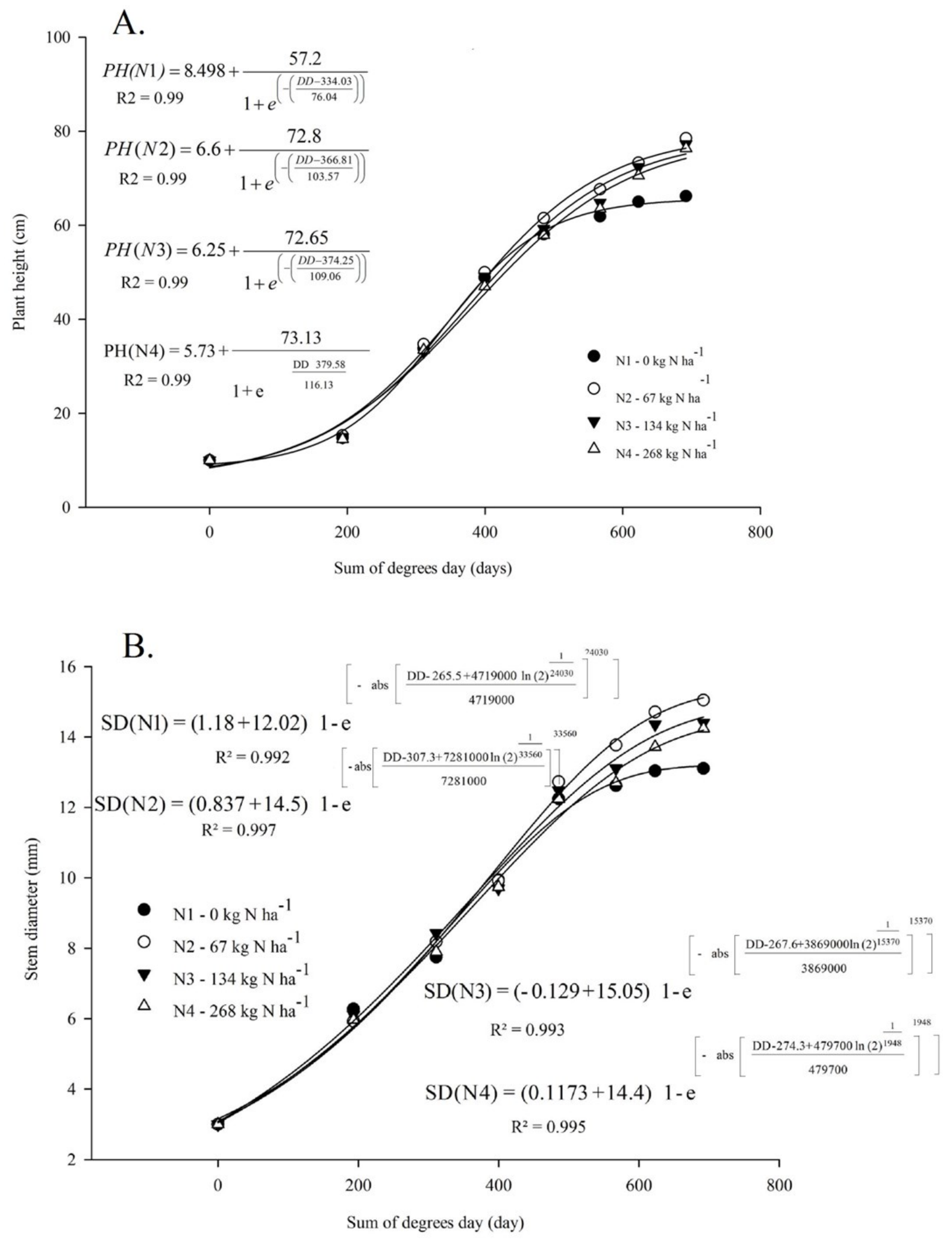

Figure 5. Plant height (A) and stem diameter (B) as a function of the sum of degrees day (DD) in eggplant subjected to different $\mathrm{N}$ doses cultivated in a protected environment. 


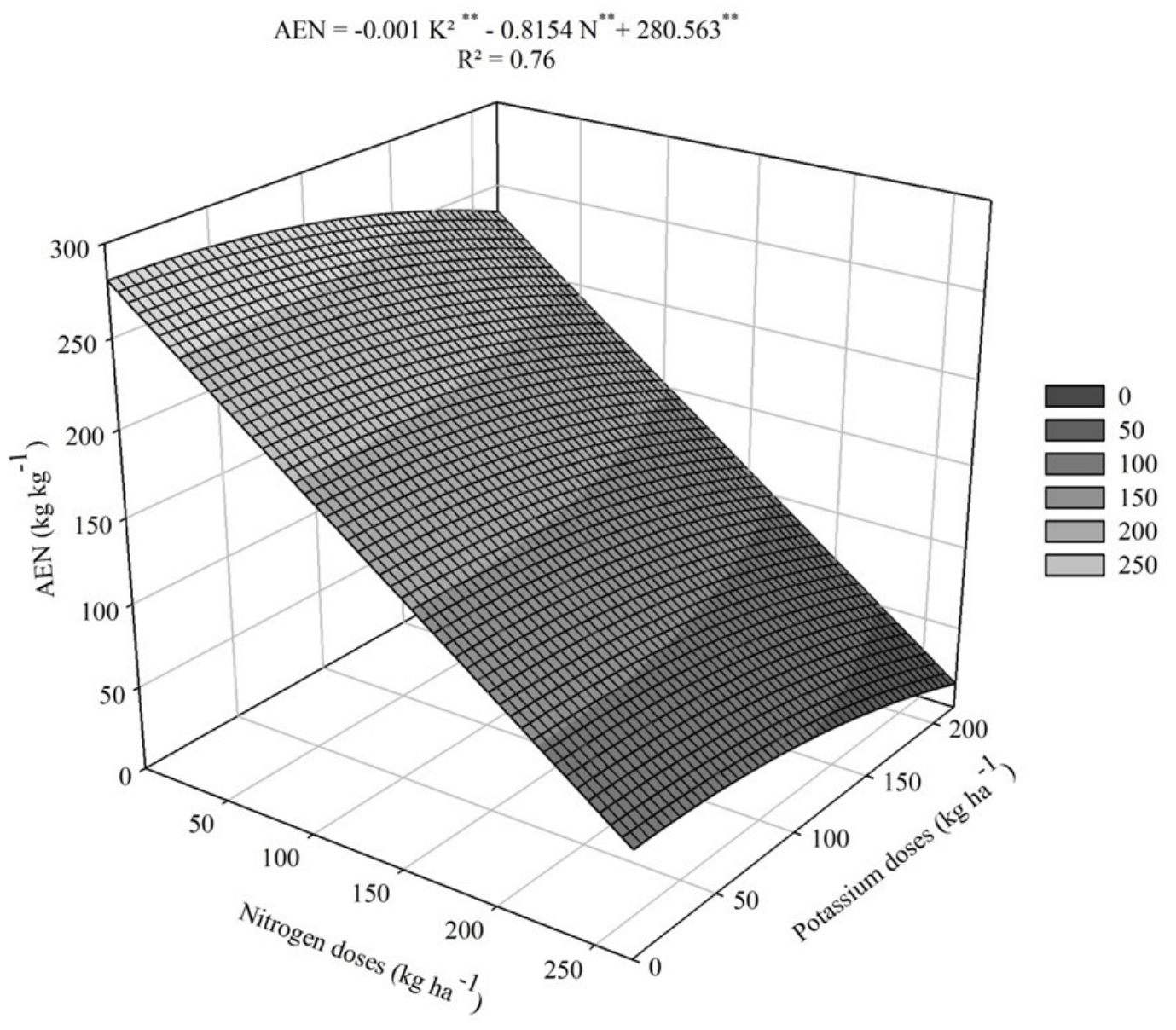

Figure 6. Agronomic efficiency of $\mathrm{N}$ as a function of $\mathrm{K}$ and $\mathrm{N}$ doses in eggplant cultivated in a protected environment.

Analysis of variance indicated significant differences in the interaction between $\mathrm{K}$ and $\mathrm{N}$ doses for AEK (Table 1). As shown in Figure 7, the highest AEK (99.5 $\mathrm{kg}$ fruit per $\mathrm{kg} \mathrm{N}$ ) was obtained with $54 \mathrm{~kg} \mathrm{ha}^{-1}$ of $\mathrm{K}$ in the level N3 $\left(134 \mathrm{~kg} \mathrm{ha}^{-1}\right)$. Oliveira et al. (2016) fertigated sweet pepper and obtained the maximum AEK value $\left(135 \mathrm{~kg} \mathrm{~kg}^{-1}\right)$ when the lowest dose was applied. Those authors concluded that nutritional efficiency was reduced when high doses of $\mathrm{K}$ and $\mathrm{N}$ were applied.

Oliveira et al. (2008) fertigated melon with $\mathrm{K}$ and $\mathrm{N}$ and reported the highest AEK (132.63 $\mathrm{kg}$ fruit per $\mathrm{kg} \mathrm{N}$ ) with the lowest doses, and showed that increasing the $\mathrm{K}$ and $\mathrm{N}$ decreased the AEK values.

Negative agronomic efficiency values are due to decreased production compared with the production of plants without $\mathrm{K}$ fertigation, probably due to salinity, as shown by Oliveira et al. (2014).

Supplying high levels of fertilizer can increase soil salinity, which initiates a series of negative effects on the cultures, such as reducing the absorption of water, inhibiting meristem activity, and cellular prolongation Oliveira et al. (2011) and, consequently, reduced agronomic efficiency of the nutrients.

In order to obtain appropriate values for the agronomic efficiency of nutrients, results from complex interactions must be considered; it does not depend solely on the availability of nutrients, but also on several metabolic activities of the vegetable, such as hormone production and the rates of photosynthesis, which can increase the absorption and use of the applied nutrients Gourley, Allan and Russelle (1994). In the present study, it is reasonable to state that high doses of the applied nutrients can reduce some of the aforementioned processes, and, therefore, the agronomic efficiency of $\mathrm{N}$ and $\mathrm{K}$.

The results obtained in this study confirm the importance of appropriate management of fertigation with $\mathrm{K}$ and $\mathrm{N}$ doses in eggplant culture conducted in a protected environment. 


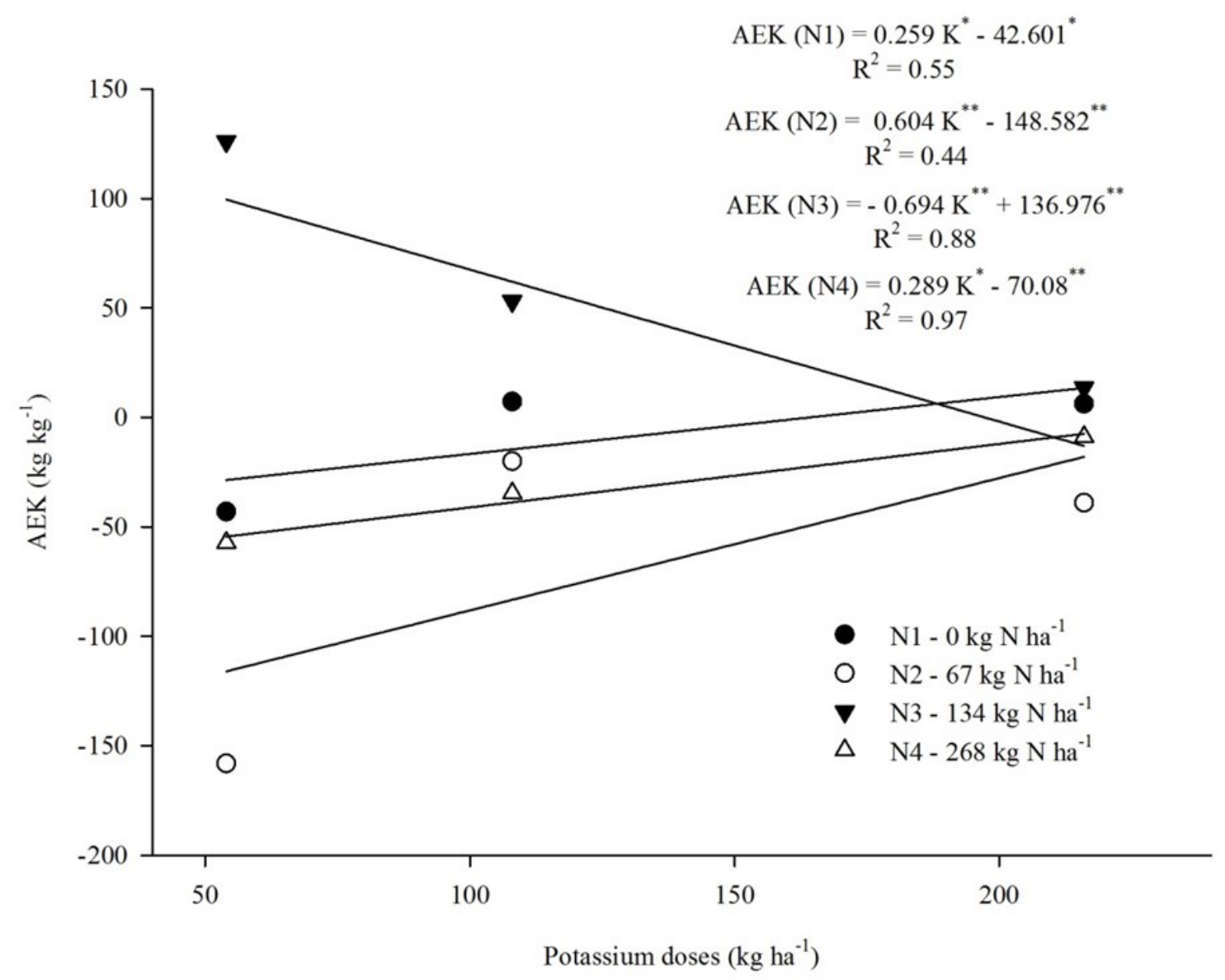

Figure 7. Agronomic efficiency of $\mathrm{K}$ as a function of $\mathrm{K}$ dose in eggplant subjected to different doses of $\mathrm{N}$ cultivated in a protected environment.

\section{CONCLUSIONS}

Maximum SD and plant height were obtained between 165 and $175 \mathrm{~kg} \mathrm{ha}^{-1}$ of $\mathrm{N}$ (16 and $17 \mathrm{~g}$ of $\mathrm{N}$ per plant). Leaf area is more influenced by the dose of $\mathrm{N}$ than of $\mathrm{K}$. The agronomic efficiency of $\mathrm{N}$ reduced with increasing $\mathrm{K}$ and $\mathrm{N}$ doses and was much more influenced by $\mathrm{N}$ application. The isolated application of different $\mathrm{K}$ doses ( 0 to $216 \mathrm{~kg} \mathrm{ha}^{-1}$ of $\mathrm{K})$ did not cause significant differences in SD, plant height, or LDM. It was possible to adjust a significant model of plant height and SD as a function of the accumulated DD of eggplant, for the cultivation conditions in the pot and in the protected environment. The nitrogen dose influenced plant height and SD, starting from 77 DAT.

\section{ACKNOWLEDGEMENTS}

The authors than Capes and $\mathrm{CNPq}$ for the respective assistance in the form of research bags received during the of the present study.
AMINIFARD, M. H. et al. Responses of eggplant (Solanum Melongena L.) to different rates of nitrogen under field condition. Journal Central European Agriculture, Bydgoszcz, v. 11, n. 4, p. 453-458, 2010.

AMIRI, E.; GOHARI, A. A.; ESMAILIAN, Y. Effect of irrigation and nitrogen on yield, yield components and water use efficiency of eggplant. African Journal of Biotechnology, Grahamstown, v. 11, n. 13, p. 3070-3079, 2012.

AUJLA, M. S.; THIND, H. S.; BUTTAR, G. S. Fruit yield and water use efficiency of eggplant (Solanum Melongena L.) as influenced by different quantities of nitrogen and water applied through drip and furrow irrigation. Scientia Horticulturae, Amsterdam, v. 112, n. 2, p. 142-148, 2007.

AZARPOUR, E. et al. Effects of bio, mineral nitrogen fertilizer management, under humic acid foliar spraying on fruit yield and several traits of eggplant (Solanum Melongena L.). African Journal of Agricultural Research, Grahamstown, v. 7, n. 7, p. 1104-1109, 2012.

\section{REFERENCES}

Rev. Caatinga, Mossoró, v. 31, n. 3, p. 737 - 747, jul. - set., 2018 
BILIBIO, C. et al. Desenvolvimento vegetativo e produtivo da berinjela submetida a diferentes tensões de água no solo. Revista Brasileira de Engenharia Agrícola e Ambiental, Campina Grande, v. 14, n. 7, p. $730-735,2010$.

BOZORGI, H. R. Study effects of nitrogen fertilizer management under nano iron chelate foliar spraying on yield and yield components of eggplant (Solanum Melongena L.). Journal of Agricultural and Biological Science, Islamabad, v. 7, n. 4, p. 233-237, 2012.

CASAROLI, D.; JONG VAN LIER, Q. Critérios para a determinação da capacidade de vaso. Revista Brasileira de Ciência do Solo, Viçosa, v. 32, n. 1, p. 59-66, 2008

EMPRESA BRASILEIRA DE PESQUISA AGROPECUÁRIA - EMBRAPA. Manual de métodos de análise de solos. 2. ed. Rio de Janeiro, RJ: Embrapa Solos, 2011. 230 p.

FAGERIA, N. K. Otimização da eficiência nutricional na produção das culturas. Revista Brasileira de Engenharia Agrícola e Ambiental, Campina Grande, v. 2, n. 1, p. 6-16, 1998.

FAQUIN, V.; ANDRADE, A. T. Nutrição mineral e diagnose do estado nutricional das hortaliças. 2004. 88 f. Curso de Pós-Graduação "Lato Sensu" (Especialização a Distância: Produção de Hortaliças) - Universidade Federal de Lavras, Lavras, 2004.

FAWZY, Z. F.; EL-NEMR, M. A.; SALEH, S. A. Influence of levels and methods of potassium fertilizer application on growth and yield of eggplant. Journal of Applied Sciences Research, v. 3 , n. 1, p. $42-49,2007$.

FELEAFEL, M. N.; MIRDAD, Z. M. Optimizing the nitrogen, phosphorus and potash fertigation rates and frequency for eggplant in arid regions. International Journal of Agriculture and Biology, Pakistão, v. 15, n. 4, p. 737-742, 2013.

FERRARI, V. J. et al. Tijolos vazados de solocimento produzidos com solo da Região do Arenito Caiuá do Paraná. Ambiente Construído, Porto Alegre, v. 14, n. 3, p. 131-148, 2014.

FRANÇA, S. et al. Nitrogênio disponível ao milho: Crescimento, absorção e rendimento de grãos. Revista Brasileira de Engenharia Agrícola e Ambiental, Campina Grande, v. 15, n. 11, p. 1143 1151, 2011.

GOURLEY, C. J. P.; ALLAN, D. L.; RUSSELLE, M. P. Plant nutrient efficiency: A comparison of definitions and suggested improvement. Plant and Soil, Crawley, v. 158, n. 1, p. 29-37, 1994.

HAAG, H. P.; HOMA, P. Nutrição mineral de Hortaliças - IV Absorção de Nutrientes pela Cultura da Berinjela. Anais da Escola Superior de Agricultura Luiz de Queiroz, Piracicaba, v. 25, n. 1, p. 177-188, 1968.

HOCHMUTH, G.; J.; HOCHMUTH, R. C.; DONLEY, M. E. Eggplant yield in response to potassium fertilization on sandy soil. HortScience, Virgínia, v. 28, n. 10, p. 1002-1005, 1993.

LIMA, P. R. et al. Effects of different rates of nitrogen $(\mathrm{N})$ and phosphorus pentoxide (P2O5) on eggplant yield. African Journal of Agricultural Research, Grahamstown, v. 9, n. 19, p. 1435-1441, 2014.

LOPES, N. F.; LIMA, M. G. S. Fisiologia da produção. 1. ed. Viçosa, MG: Editora UFV, 2015. $492 \mathrm{p}$.

MARQUES, D. J. et al. Dinâmica de cátions na raiz e folhas de berinjela cultivada sobre doses crescentes de potássio oriundas de duas fontes. IDESIA, Tarapacá, v. 29, n. 2, p. 69-77, 2011.

MELO, A. S. et al. Crescimento, produção de biomassa e eficiência fotossintética da bananeira sob fertirrigação com nitrogênio e potássio. Revista Ciência Agronômica, Fortaleza, v. 41, n. 3, p. 417426, 2010.

MINAMI, K.; SIMÃO, S.; MANTOVANI, W. Análise de crescimento da berinjela (Solanum melongena L.). Anais da Escola Superior de Agricultura Luiz de Queiroz, Piracicaba, v. 37, n. 1, p. 63-70, 1980 .

MIRDAD, Z. M. Vegetative Growth Yield and Yield Components of Eggplant (Solanum melongena L.) as Influenced by Irrigation Intervals and Nitrogen Levels Zohair. Journal of King Abdulaziz University: Meteorology, Environment, Jeddah, v. 22, n. 1, p. 31-49, 2011.

OLIVEIRA, F. A. et al. Eficiencia agronomica da fertirrigacao nitrogenada $\mathrm{E}$ potassica na cultura do meloeiro nas condicoes do semiarido nordestino. Revista Caatinga, Mossoró, v. 21, n. 5, p. 5-11, 2008 .

OLIVEIRA, F. A. et al. Desenvolvimento e concentração de nitrogênio, fósforo e potássio no tecido foliar da berinjela em função da salinidade. Revista Brasileira de Ciências Agrarias, Recife, v. 6, n. 1, p. 37-45, 2011 . 
OLIVEIRA, F. A. et al. Interação entre salinidade da água de irrigação e adubação nitrogenada na cultura da berinjela. Revista Brasileira de Engenharia Agrícola e Ambiental, Campina Grande, v. 18, n. 5, p. $480-486,2014$.

OLIVEIRA, F. A. et al. Eficiência da fertirrigação nitrogenada e potássica na produção de pimentão cultivado em ambiente protegido. Amazonian Journal of Agricultural and Environmental Sciences, Belém, v. 59, n. 3, p. 293-301, 2016.

OLONIRUHA, J. A. Effect of Graded Levels of Nitrogen on Growth and Yield of Eggplant (Solanum Melongena) in Kabba, Southern Guinea Savanna Ecological Zone of Nigeria. Journal of Life Sciences, New Delhi, v. 5, n. 9, p. 725-727, 2011.

OMETTO, J. C. Bioclimatologia vegetal. 1. ed. São Paulo, SP: Agronômica Ceres, 1981. 440 p.

PEEL, M. C.; FINLAYSON, B. L.; MCMAHON, T. A. Updated world map of the Koppen-Geiger climate classification. Hydrology and Earth System Sciences, Munich, v. 11, n. 1, p. 1633-1644, 2007.

SILVA, F. G. et al. Trocas gasosas e fluorescência da clorofila em plantas de berinjela sob lâminas de irrigação. Revista Brasileira de Engenharia Agrícola e Ambiental, Campina Grande, v. 19, n. 10, p. 946-952, 2015.

TRANI, P. E.; TIVELLI, S. W.; CARRIJO, O. A. Fertirrigação em hortaliças. 2. ed. Campinas, SP: Instituto Agronômico, 2011. 58 p. 